\title{
27 Mayıs ile 12 Mart Arası Dönemde Muhalefetin Sembol İsmi: Osman Bölükbaşı
}

\author{
The Symbol Name of the Opposition between 27 May and 12 March: \\ Osman Bölükbaşı
}

\author{
ADEM ÇAYLAK $\quad$ CANSU KAYMAL Ç* $^{*}$ \\ * Prof., Kocaeli University, Department of Political Science and Public Administration, Umuttepe \\ Yerleşkesi, 41001, İzmit, Kocaeli, Turkey. E-mail: ademcaylak@gmail.com \\ (D) https://orcid.org/0000-0003-3198-2353 \\ ** Res. Asst., Kocaeli University, Department of Political Science and Public Administration, \\ Umuttepe Yerleşkesi, 41001, İzmit, Kocaeli, Turkey. E-mail: kaymal.cansu@gmail.com \\ (D) https://orcid.org/0000-0002-9265-8779
}

Öz: Türkiye'nin siyasal hayatında muhalif duruş konusunda, akla ilk gelen siyasi aktörlerden biri Osman Bölükbaşı'dır. Çok partili hayata geçiş sürecinde siyasete Demokrat Parti'de başlayan Bölükbaşı, iktidar partisi Cumhuriyet Halk Partisi’ne muhalefetini yetersizgördüğü DP'ye karşı kendi müstakil hareketini kurmuştur. Makalenin amacı, Bölükbaşı’nın 27 Mayıs darbesi ile 12 Mart muhtırasına bakış açısını ve bu iki dönem arasındaki muhalefetini değerlendirmektir. Bu bağlamda, makale Bölükbaşı'nın başlattı̆̆ı hareketin DP, CHP, 27 Mayıs cuntası ve Adalet Partisi tarafından bastırılmak istenmesine karşı verdiği mücadeleye odaklanmaktadır. İlk kısımda, Bölükbaşı'nın kişisel ve siyasi yaşamı gözden geçirilmiştir. Takip eden kısımlarda Bölükbaşı'nın benimsediği siyasi muhalefet tarzı, DP iktidarı öncesi, sirası ve sonrası, özellikle 27 Mayıs-12 Mart dönemi olmak üzere farkl evrelerde incelenmiştir. Doktora tezine dayanan bu nitel araştırmada döneme ilişkin Meclis ve gazete arşivlerinin yanı sıra birincil kaynak niteliğindeki hatıra ve kitaplardan yararlanılmıştır.

Anahtar kelimeler: Osman Bölükbaşı, Muhalefet, Darbe, 27 Mayıs, 12 Mart

Abstract: Osman Bölükbaşı is one of the most eminent political actors that comes to mind due to his dissenting stance in Turkey's political life. He started politics in the Democratic Party during the transition to multiparty life and founded his own independent movement against the ruling Republican People's Party and the DP, whose opposition he deemed inadequate. The aim of the article is to shed light on Bölükbassi's views on the May 27 coup and the March 12 memorandum, and his opposition between these two terms. In this context, the article focuses on the struggle of the movement initiated by Bölükbașı against the suppressive attempts of the CHP, DP, the 27 May junta and the Justice Party. In the first part, the personal and political life of Bölükbaşı is reviewed. In the following sections, the style of the political opposition that Bölükbaș had adopted was examined in various phases, namely before, during and after the DP's rule, especially the period from 27 May to 12 March. In this qualitative research based on the doctoral thesis, primary source memories and books were used, as well as the archives of the Parliament and newspapers of the period.

Keywords: Osman Bölükbaşı, Opposition, Coup, May 27, March 12 


\section{Giriş}

Türkiye'nin siyasal hayatının en önemli dönüm noktalarına damgasını vurmuş aktörlerden biri olan Osman Bölükbaşı, çok partili siyasi hayata geçiş, DP iktidarı, 27 Mayıs darbesi, 12 Mart muhtırası gibi dönemlerde siyasi muhalefetin odak noktası olmuştur. Dilinin kemiği olmayan, retorik ve hitabet yeteneğiyle dikkat çeken Bölükbaşı, çok partili siyasal hayatın başladığı 1946 yılından 12 Mart muhtırasına kadar üçüncü büyük siyasi partinin lideri olarak hem iktidar ve hem de muhalefete ilişkin eleştirel bir perspektifi haiz olan, uzlaşmaz ve sorgulayıcı yönü ile rakiplerinin karşısında konuşmaktan çekindiği bir lider portresidir.

Bölükbaşı, 1 Mart 1911'de Kırşehir'in Hasanlar köyünde doğmuştur. Babası Hacı Ahmet Ağa, varlıklı bir çiftçi ve tüccardır. Annesi Fatma Hanım, Bölükbaşı çok küçükken verem hastalığından ölmüştür. Bölükbaşı, Hasanlar köyünde okul olmadığı için 1922 yılında göç ettikleri Kırşehir'de ilkokula başlamıştır. Bölükbaşı'nın ilkokulda zeki ve başarılı bir öğrenci olarak başladığı eğitim hayatı, üniversiteyi bitirene kadar aynı şekilde devam etmiştir. Bölükbaşı, ortaokulu Kırşehir'de bitirmiştir. Fakat Kırşehir'de lise olmadığından 1927'de İstanbul Erkek Lisesi'ne gitmiştir. 1933’te liseyi “pekiyi” derecesiyle bitiren Bölükbaşı, Milli Eğitim Bakanlığı'nın üniversite eğitimi için açtığı burslu sınavı kazanarak, üniversite tahsili için Fransa'ya gitmiştir. Bölükbaşı, Fransızca öğrenmek için Bordeaux'da Victor Hugo Lisesi'nde eğitim almıştır. Nancy şehrindeki Nancy Üniversitesi Fen Fakültesi Matematik ve Astronomi Bölümü'nden 1937'de mezun olmuştur. İstanbul'a başarılı bir matematikçi olarak dönen Bölükbaşı, 1938 yılında Kandilli Rasathanesi Mülazımlığı'na tayin edilmiştir. Döneminin meşhur matematikçisi Kandilli Rasathanesi müdürü Mehmet Fatin Gökmen'in, Bölükbaşı'nın siyasete atılmasında büyük bir rolü olmuştur. Bölükbaşı 1940'ta Haydarpaşa Lisesi'ne stajyer matematik öğretmeni olarak atanmıştır. Aynı kurumda bir yıl çalıştıktan sonra öğretmenliğe yükselmiştir. 1941 sonlarından itibaren yapmaya başladığı askerlik görevini tamamladıktan sonra 1944 yılının ortalarına dek Haydarpaşa'da öğretmenlik görevine devam eden ve nihayetinde memleketi Kırşehir'e dönen Bölükbaşı, babasılyla beraber kendi çiftliklerinde tarımla ve ticaretle meşgul olmuş ve 1946 yılında siyasete atılmıştır. ${ }^{1}$

Çok partili siyasi hayata geçişle birlikte, CHP’nin baskıcı tek parti yönetiminin 'jandarma dipçiği, hukuksuz uygulamaları ve vergi tahsildarının sömürüsünden' müşteki olan ve "çevre"yi temsil eden ve ideoloji, felsefe, din ve dünya görüşleri açısından son derece heterojen bir yapı sergileyen aydın ve bürokratlar, yeni kurulan DP etrafında toplanmıştır. Bölükbaşı da tek parti dönemi CHP'sinin istibdadından rahatsız aydınlar arasındadır. Döneminin hürriyet mücadelesinde etkin olma arzusunda olan Bölükbaşı, babasından gelen tepkilere rağmen siyasete girmiştir. ${ }^{2}$ Mehmet Fatin Gökmen hoca, Dil Tarih Coğrafya Fakültesi hocalarından Mehmet Altay Köymen aracılığıyla Bölükbaşı'yı DP kurucularından olan Fuat Köprülü'ye tavsiye etmiş, Köprülü ise Bölükbaşı'yı DP’nin diğer kurucuları ile tanıştırmıştır. ${ }^{3}$ DP kurucuları, Bölükbaşı’nın güçlü hitabet kabiliyetinden etkilenmiş ve onu DP'nin Orta Anadolu müfettişliği ile vazifelendirmişlerdir. ${ }^{4}$ DP'den istifa

\footnotetext{
${ }^{1}$ Adem Çaylak, “Türk Siyasal Hayatında Osman Bölükbaşı, Doktora Tezi, Ankara Üniversitesi, 2004, s.53.

${ }^{2}$ Çaylak, "Türk Siyasal Hayatında Osman Bölükbaşı", s.60.

${ }^{3}$ Samet Ağaoğlu, Aşina Yüzler, İstanbul: Ağaoğlu Yay., 1956, s.56.

${ }^{4}$ Cihad Baban, Politika Gazetesi: Büstler ve Portreler, İstanbul: Remzi Kitabevi, 1970, s.400.
} 
edene kadar da Samet Ağaoğlu ile birlikte DP’nin Türkiye müfettişliği görevi çerçevesinde DP'nin pek çok il ve ilçe yönetimlerinin kuruluşunda aktif rol oynamıştır.

Karadeniz'de ve Orta Anadolu'da DP'nin teşkilatlanmasında aktif rol almış olan Bölükbaşı, henüz yolun başında olduğu dönemlerde bile "Anadolu Fırtınası" lakabıyla anılmıştır. ${ }^{5}$ Bölükbaşı'nın temel meselesi daima "hürriyet" ve "demokrasi" olmuş ve daima denetimsiz tek parti sistemini tasfiye etmenin milletin kurtuluşu olduğunu vurgulamıştır. ${ }^{6}$

DP, ilk kurulduğunda iktidar tarafından bir tehdit olarak algılanmamış ${ }^{7}$, fakat Bölükbaşı gibi tek parti ideolojisine karşı koyan sert üsluplu kimselerin katılmalarıyla birlikte CHP’nin DP ile ilişkileri gerilmeye başlamıştır. Kenan Öner, Hikmet Bayur, Bölükbaşı vb. bu isimlerin ortak özellikleri CHP içinden gelmemeleridir. ${ }^{8}$ CHP ile DP ihtilafları, iki partiyi de mutediller ve müfritler olarak iki kola ayırmıştır. DP’nin ve kurucu kesiminin İsmet İnönü CHP'siyle muvazaa hâlinde olduğunu iddia eden müfritlerin içinde yer alan Bölükbaşı, 1947 yılında DP'den istifa etmiştir. DP'nin içinden gelen Mareşal Fevzi Çakmak, Mustafa Kentli, Sadık Aldoğan, Hikmet Bayur, Osman Nuri Köni, Ahmet Tahtakılıç gibi muhaliflerle birlikte 1948'de MP’yi (Millet Partisi) kurmuştur. 1950 seçimlerinde Bölükbaşı, MP saflarından Meclis'e giren tek milletvekili olmuş ve şöhreti günden güne artmaya başlamıştır.

MP'liler, gerçek muhalefeti kendilerinin ettiklerini, CHP ile DP'nin aralarında anlaştıklarını iddia etmişlerdir. Siyasi kültürün gerçek bir muhalefete izin vermediği sosyo-politik şartlarda varoluş mücadelesi veren Bölükbaşı hareketinin ilk halkası olan MP, "laikliğe aykırı politikalar ürettiği” gerekçesiyle 1954 yılında kapatılmış ve yerine Bölükbaşı başkanlığında CMP (Cumhuriyetçi Millet Partisi) kurulmuştur. CMP, 1958 yılında Cumhuriyetçi Köylü Partisi ile birleşerek iki parti CKMP (Cumhuriyetçi Köylü Millet Partisi) adıyla yine Bölükbaşı liderliğinde hem iktidarın hem de muhalefetin muhalefeti olarak faaliyet göstermiştir. CKMP içinde çıkan anlaşmazlıklar sonucunda Bölükbaşı bu partiden ayrılarak 1962 yılında tekrar MP'yi kurmuş ve 1965 yılında kurulan AP-YTP (Yeni Türkiye Partisi)-MP-CKMP koalisyon hükümetine katılmıştır. 1972 yılında MP Genel Başkanlığı'ndan ve partiden ayrılmış, 1973'te ise politikaya, 6 Şubat 2002'de ise hayata veda etmiştir.

Sert üslubu, hazır cevaplılığı, espri yeteneği ve ilkelerinden taviz vermemesiyle dikkat çeken Bölükbaşı'nın siyasi hayatı, Türkiye'nin siyasal hayatının dönüm noktalarında, Türkiye'nin siyasi kültüründe muhalefete karşı olan tutumu anlamak bakımından önemlidir. Zira Bölükbaşı’nın muhatap olduğu "müfrit”, "gerici” gibi yakıştırmalar, günümüze dek muhalefetin susturulma nedeni olagelmiştir. Ordunun, sivil siyasetin popülist ve dinî eğilimlerinin karşısında laikliğin bekçiliği misyonunu üstlendiği ve belli aralıklarla siyasetin darbeler, darbe girişimleri ve muhtıralar ile muhatap olduğu Türkiye siyasetinde; Bölükbaşı'yı, onun öncülüğündeki muhalif hareketin darbelere olan bakışını anlamak açısından çalışmanın önemli olduğu düşünülmektedir.

\footnotetext{
${ }^{5}$ Çaylak, "Türk Siyasal Hayatında Osman Bölükbaşı", s.62.

6 Başkent, 18.11.1946.

${ }^{7}$ Necmettin Sadak, "Demokrat Partiye Hoş Geldin Deriz", Akşam, 09.01.1946.

${ }^{8}$ Çaylak, "Türk Siyasal Hayatında Osman Bölükbaşı”, s.64.
} 


\section{6-1950 Yılları Arasında Osman Bölükbaşı}

Cumhuriyetin kurucu partisi olan CHP’nin kurulma amacı, Osmanlı devlet sisteminden demokratik bir cumhuriyete geçiş için gerekli olan yeniliklerin yapılmasıdır. ${ }^{9}$ Ancak şekli reformlardan ibaret bu dönüşüm çabaları demokrasinin ruhunu yakalamak ve toplumsal düzeyde içselleştirmekten son derece uzak kalmıştır.

Çok partili siyasal hayatın başlamasıyla birlikte, tek parti idaresinden memnun olmayan toplum kesimlerinin DP'de toplandığı ve türdeş olmayan bir muhalefet kitlesinin oluşumu söz konusu olmuştur. DP, siyasal merkeze karşı, dağınık çevresel odakların sesi olan bir partiydi. ${ }^{10}$ Dönemin şartlarında muhtelif toplum kesimlerine dayanan ${ }^{11} \mathrm{DP}$, halkta birikmiş muhalefeti açığa çıkardığı gibi, muhafazakâr bir gelenekten gelen aydınları da çevresinde toplamıştır. Bölükbaşı, bu aydınlardan biridir.

Orta Anadolu'nun bağrından gelmiş ve bu coğrafyadaki insanların dilinden anlayan, hitabeti güçlü bir siyasetçi olarak Bölükbaşı, DP’nin teşkilatlanmasında çok önemli bir rol oynadığı gibi, CHP'nin politikalarına yönelik eleştirileri CHP iktidarı ile DP muhalefeti arasındaki ilişkileri iyice germişti. DP’nin hızlı teşkilatlanması CHP'yi endişelendirmiş ve tek dereceli seçimlerin 21 Temmuz 1946 yılında yapılmasına karar verilmişti. 21 Temmuz seçimlerinde DP’nin Kırşehir dahil olmak üzere 16 ilde adayı yoktu ve bu yüzden Bölükbaşı Yozgat'tan milletvekilliğine aday olmuş ve 93 binden çok oyu olsa bile CHP’nin seçimlerde yolsuzluk yaptığ1 iddialarıyla seçim sonuçlarına itiraz ettiği için milletvekili seçilememiştir. Bu olayın sonucunda Bölükbaşı'ya, İnönü'ye hakaretten dava açılmış ve Bölükbaşı Sorgun cezaevine gönderilmiş; ardından, Yozgat Ağır Ceza Mahkemesi tarafından serbest birakılmıştı. ${ }^{12}$

DP içindeki ilk bölünmenin, bu seçimlerden hemen sonra yaşandığ 1 görülmektedir. Bütün DP'liler CHP’nin iktidar kaygısıyla apar topar seçim kararı aldığı ve seçimlerde yolsuzluk yaptığı konusunda hemfikir olsa bile, 21 Temmuz seçimlerinden sonra DP, "çözümü yine siyasette ve parlamentoda arama yanlıları" ile "meclisi terk etme yanlıları" olarak ikiye bölünmüştür. Çözümü siyasette ve parlamento içinde arayanlar, CHP'den ayrılıp DP’yi kurmuş olan Celal Bayar, Fuat Köprülü, Adnan Menderes ve Refik Koraltan gibi isimler iken; meclisi terk etme ve sine-i millete dönme tarafında olup kurucuların mutedil politikalarından hoşlanmayanlar arasında; Kenan Öner, Fevzi Çakmak, Tevfik Rüştü Aras, Cami Baykurt, Bölükbaşı, Sabiha-Zekeriya Sertel gibi "müfrit" isimler vardı. Seçimlerden sonra beliren bu ayrışmayı, CHP’li Recep Peker hükümetinin varlığı daha da körüklemiştir. ${ }^{13}$ Peker'in politikaları DP içinde seçimlerle başlayan ayrılıkları körüklediği gibi, CHP içinde de ılımlı olanlar ile daha katı görüşlere sahip olanlar arasında ayrışmayla sonuçlanmıştır. ${ }^{14}$

DP’nin 7 Ocak 1947'deki ilk kongresinde 27 Mayıs darbesine kadar sürecek olan parti içi çatışmaların başlangıcı yaşanmıştır. Kongrede aralarında Bölükbaşı’nın da

\footnotetext{
${ }^{9}$ Arda Can Kumbaracıbaşı, “Cumhuriyet Halk Partisi Oylarının Birikimli Düzey Analizi ve Türkiye’de Merkez Solun Seçim Coğrafyasının İncelenmesi”, Amme İdaresi Dergisi, $47 / 4$ (2014), s.65.

${ }^{10}$ Şerif Mardin, Türkiye'de Toplum ve Siyaset, İstanbul: İletişim, 1991, s.57.

${ }^{11}$ Çağlar Keyder, Türkiye'de Devlet ve Sinıflar, İstanbul: İletişim, Üçüncü Baskı, 1993, s.170.

${ }^{12}$ Çaylak, "Türk Siyasal Hayatında Osman Bölükbaşı", s.64-66.

${ }^{13}$ Metin Toker, Tek Partiden Çok Partiye, İstanbul: Milliyet Yay., 1970, s.189.

${ }^{14}$ Kemal, H. Karpat, Türk Demokrasi Tarihi, İstanbul: Timaş Yay., 2010, s.258.
} 
bulunduğu "müfrit" isimlerin meclisten çekilme isteğine karşın, parti kurucularının meclisten çekilmeyle oluşabilecek ihtilal endişeleri gündeme gelmiştir. ${ }^{15}$ Kongre'ye Bölükbaşı'nın, iktidarı sert bir üslupla eleştiren konuşmaları damgasını vurmuştur. Bölükbaşı, daha sonra bir kişiyi değil, bir zihniyeti kastetmek istediğini ifade ettiği "bu memleket 23 senedir klzul bir sultan idaresinde sevk ve idare olundu" cümlesini kurmuştur. Kongrede DP, CHP'yi vatandaş hak ve hürriyetlerine ilişkin anayasal düzenlemeler konusunda daha duyarlı olmaya ve parti başkanlığı ile devlet başkanlığını birbirinden ayırmaya çağıran Hürriyet Misakı'nı sunmuştur. Bölükbaşı, Hürriyet Misakı'nın uygulanması gerektiğini ifade etmiştir. ${ }^{16}$

Celal Bayar, 21 Temmuz seçiminden sonra başlayan anlaşmazlıklar, çözüme kavuşturulmazsa çok partili rejim çıkmaza sürüklenebilir endişesine sahipti. ${ }^{17} \mathrm{Bu}$ nedenle iktidarla muhalefetin uzlaştırmasına yönelik çabalar başlamıştır. İktidar ile muhalefetin iki akademisyeni olan Nihat Erim ve Fuat Köprülü arasında, kamuoyunda bahar havası olarak isimlendirilen ılımlı fasılalar, dönem içinde yaşanır olmuştu. Köprülü, Erim kanalıyla iktidara birtakım teminatlarda bulunmuş ve CHP’nin Demokratların istediği birtakım demokratik tedbirleri alması karşılığında DP'nin aşırı propaganda usullerinden vazgeçmesi ve içindeki müfritleri kontrol etmesi konusunda uzlaşılmıştı. İnönü ve Bayar görüşmeleri sonucunda karşılıklı verilen vaatler ve anlaşmalarla 12 Temmuz Beyannamesi bizzat İnönü tarafından halk efkârına ilan edilmişti. ${ }^{18}$

12 Temmuz Beyannamesi sonucunda CHP'de sertlik yanlısı olan Recep Peker'e karşı parti içi bir hizip bizzat İnönü tarafından harekete geçirilmiş ve istifa etmek mecburiyetinde kalan Peker yerine daha mutedil bir isim olan Hasan Saka hükümeti kurulmuştur. DP'de içinde ise çok daha büyük gerilimler yaşanmış, parti içinde Bölükbaşı'nın da aralarında bulunduğu müfrit grup Celal Bayar ve diğer DP’lileri “milli şef”e boyun eğen "muvazaacılar” olmakla suçlamış ${ }^{19}$ ve Mareşal Fevzi Çakmak'ın fahri başkanlığında gerçekte bir Bölükbaşı hareketi olan Millet Partisi bu gelişmeler sonucunda kurulmuştu. ${ }^{20} 20$ Mayıs 1948'de resmen kurulan MP'nin kurucularından olan Yusuf Hikmet Bayur, partinin kuruluşunu; halkın mevcut iktidardan bıkmış olması, muhalefetin iktidarla işbirliği içinde olması ve muhalefetin yeterli görülmemesi gibi nedenlere dayandırmıştır. ${ }^{21}$ Bu kuruluştan itibaren parti kuruculularının önlerine zorlukları çıkarılmaya başlanmıştır. Bunlardan ilki Celal Bayar ve İsmet İnönü’ye suikast hazırladığı iddialarıyla Bölükbaşı ve Fuat Arna'nın tutuklanmalarıdır. 17 Kasım 1949'da tutuklanan ve 21 Kasım günü serbest bırakılan Bölükbaşı, olayın MP’ye marşı kurulan bir tuzak olduğunu ifade etmiştir. ${ }^{22}$

MP, siyasi alanda liberal görüşleri savunmasına mukabil, kültürel ve toplumsal konularda muhafazakâr bir tutum izlemiştir. 1949 yılında Kenan Öner ile 1950’de

\footnotetext{
${ }^{15}$ Celal Bayar, Başvekilim Adnan Menderes, İstanbul: Baha Matbaası, 1969, s.71.

${ }^{16}$ Çaylak, "Türk Siyasal Hayatında Osman Bölükbaşı", s.70-80

${ }^{17}$ Cem Eroğul, Demokrat Parti, İstanbul: İmge Yay., 1990, s.55.

${ }^{18}$ Erik Jan Zürcher, Modernleşen Türkiye Tarihi, İstanbul: İletişim, 2000, s.311-312.

${ }_{19}$ Türk solunun önde gelen isimlerinden Abidin Nesimi de bu iddiayı ileri sürmekte, başlangıçta muvazaa olmayı kabul eden Bayar'ın, verdiği sözü tutmayarak iktidar olmaya gayret etmesinin İnönü’yü kızdırdığını iddia etmektedir. Bkz. Abidin Nesimi, Yılların İçinden, İstanbul: Gözlem Yayınları, 1977, s.211-212; bu kaynağa dikkatimizi çeken şu çalışmaya bkz. Cengiz Sunay and Emrullah Ataseven, "Prelude to a coup, the press and the May 27 1960", Current Research in Social Science, 3/3 (2017), s.146.

${ }^{20}$ Zürcher, Modernleşen Türkiye Tarihi, s. 312; Çaylak, “Türk Siyasal Hayatında Osman Bölükbaşı”, s.81-138.

${ }^{21}$ Hikmet Bayur, "Millet Partisi", Kudret, 20.07.1948.

${ }^{22}$ Çaylak, "Türk Siyasal Hayatında Osman Bölükbaşı”, s.162-168.
} 
Mareşal Fevzi Çakmak gibi muteber kişilerin vefatı partiyi zayıflatmıştır. Ayrıca Mareşal'in cenaze törenindeki olaylar, MP'nin laiklik karşıtı söylem ve davranışların odağı olduğu izlenimi ile büyük bir antipati uyandırmıştır. 14 Mayıs 1950 seçimlerinde MP, 8 milyon oydan ancak 240.209'unu alabilmiş ve sadece bir milletvekili çıkarabilmiştir. ${ }^{23} \mathrm{Bu}$ milletvekili ise 14 Mayıs seçimlerinde seçim meydanlarının yıldızı olan ve kendi memleketi olan Kırşehir'den seçilen Bölükbaşı'dır.

MP, kuruluşundan itibaren laiklik karşıtlığ ve dini siyasete alet etme gibi tenkitlerle karşı karşıya kalmıştır. Bölükbaşı, Cumhuriyet maskesiyle zümre saltanatını sürdürenlerin "siyasi irticayı" yaşattıklarını, MP'nin, CHP ve DP'nin ortak iftiralarına maruz kaldığını, MP'yi yok etme amacıyla "dini irtica” yalanlarını ortaya attıklarını ifade etmiştir. ${ }^{24}$

Birtakım gerçekler göz önünde bulundurulduğunda Bölükbaşı’nın haklılık payı olmadığını söylemek mümkün değildir. Cumhuriyet'in kurucuları her ne kadar orduyu siyasetin dışında tutma politikası gütmeye çalışmışlarsa da orduyu laikliğin nihai koruyucusu olarak sunmuşlardır. Ordunun profesyonelliği henüz cumhuriyetin erken dönemleri olan tek partili yıllarda bozulmaya başlamıştır. Bu zaman zarfında cumhuriyet aydınlanması ve modernleşmesine entegre olan memurlar, yirmi yıldan fazla bir süre devam eden tek parti yönetiminin demokrasisinden tatmin olmamışlar ve bu aydınlar DP'yi desteklemişlerdir. ${ }^{25}$ Ancak yine de aralarına DP'nin kurucularının da dahil olduğu bu aydınların pek çoğu laiklik konusunda tek parti döneminin yönetici kadrolarından pek farklı politikalar gütmemişlerdir.

Çoğunluk seçim sistemine göre yapıldığı için temsilde adalet ilkesiyle pek bağdaşmayan 14 Mayıs 1950'de yapılan seçimlerde DP’nin oyu \%55,2'dir.Tek başına iktidar olan DP, 416 milletvekili çıkarmıştır. CHP ise \%39,6 oy oranı ile 69 milletvekili çıkarmıştır. MP, \%4,6 oy oranı ile sadece Bölükbaşı'yı meclise gönderebilmiştir. Böylece MP ile başlayan hareket "muhalefetin muhalefeti” bir hareket olarak, Bölükbaşı ise sivri dili, uzlaşmaz tavrı ve eteğinde taş bırakmaz üslubu ile Türkiye'nin siyasal hayatındaki nev-i şahsına münhasır yerini almıştır.

\section{0-1960 Arasında Osman Bölüikbaşı}

14 Mayıs seçimlerinden sonra Bölükbaşı, mecliste MP’nin tek temsilcisi olmuş ve DP milletvekillerinin karşısında etkili bir muhalif söylem geliştirmiştir. Bölükbaşı, Menderes hükümetini "tek parti zihniyetini devam ettirmek" ile suçlamıştır. Menderes'in ilk meclis konuşmasında "devr-i sâbık yaratmayacağız" biçiminde özetlenebilecek sözlerinden yola çıkarak, Bölükbaşı, "devr-i sâbık yaratılmadıkça demokrasinin memlekette tam anlamıyla kurulup gelişmesinin mümkün olmadığını” ifade etmiştir. Bu bakımdan Bölükbaşı'nın DP ve Menderes'ten çok daha keskin ve farklı bir içerikte, Atatürk ilke ve inkılapları temelinde olmasa da tek parti dönemine damgasını vuran devrimci çizginin karşısında tam bir karşı-devrimci çizgiye sahip olduğu söylenebilir. Bölükbaşı’nın iddiasına göre DP kurucuları “46 Ruhu”nu söndürmüş ve demokrasi davasına ihanet etmiştir. Bu itibarla DP, içinden çıktığ1 CHP'ye benzemiştir. ${ }^{26} \mathrm{Bu}$ durum, DP henüz muhalefette olduğu dönemlerdeyken

\footnotetext{
${ }^{23}$ Karpat, Türk Demokrasi Tarihi, s.508.

${ }^{24}$ Kudret, 29.04.1950.

${ }^{25}$ Metin Heper, "Special Issue on Civil Military Relations in Turkey Introduction", Turkish Studies Journal, 12/2 (2011), s.175. (erişim 3.06.2021)

${ }^{26}$ Çaylak, “Türk Siyasal Hayatında Osman Bölükbaşı”, s.197-200.
} 
partinin içerisinde beliren farklı görüş ve düşünceleri antidemokratik yollarla susturduğu gerçeğine bakılarak daha iyi anlaşılabilir.

1950 seçimleri sonrasında MP saflarından Meclise giren yegâne vekil olan Bölükbaşı'nın şöhreti günden güne artmaya başlamıştır. Ona göre esas şöhret kazandıran niteliği etkili hitabet sanatıdır. Bölükbaşı, 1950-1960 yılları arasında adından sıklıkla bahsettirmiştir. Bölükbaşı, DP'nin çoğunluğun tiranlı̆̆ına varabilecek uygulamalarına karşı yalnız ve dimdik muhalefet etmeyi başarabilmiştir. Menderes'in, başbakan olduğu yıllardaki en büyük kâbusunun Bölükbaşı olduğu iddia edilmektedir. $^{27}$

Bölükbaşı, mecliste muhalefet yapmaya başladığı 1950'den itibaren çift meclis sistemine geçilmesi, nispi temsil usulüyle seçimlerin yapılması gerektiğini, anayasaya aykırı yasaların iptal edilmesi için Anayasa Mahkemesi'nin kurulmasının zorunlu olduğunu savunmuş, yıkıcı sol cereyanları reddettiklerini belirtmiştir. Din işlerinin siyasi meselelere karışmasının sakıncalı olması gibi, siyasetin de din alanını tahakkümü altına almasının sorunlu olduğunu vurgulayarak dinin cemaatlerin elinde özerk bir kurum olarak kalması gerektiğini vurgulamıştır. Partisinin dış politika ve iktisadi sahadaki görüşlerini anlatan Bölükbaşı, kimi zaman Menderes tarafından kindar olmakla suçlanmış ve cevap vermek üzere söz istediğinde kendisine söz hakkı tanınmayınca çoğu kez, CHP milletvekilleriyle beraber Genel Kurul'dan ayrilmıştır. ${ }^{28}$

1951 yılında Kırşehir'de Ticaniler tarikatı mensupları tarafından Atatürk heykelinin kırılması, ${ }^{29}$ siyasi partiler arasında din, laiklik, Atatürk ilke ve inkılapları gibi konularda tartışmalara yol açmış, tenkit ve itham okları özellikle MP ve-Bölükbaşı'ya yönelmiştir. Bölükbaşı, hadiseyi kınayan sert bir beyanname yayınlamıştir. $^{30}$

MP'nin ilk ve ikinci kongrelerinde Atatürk'ün mezarına çelenk konulma konusunda tartışmalar yaşanmıştır. İkinci Kongre'de partide dinin siyasete alet edilmesini reddetme, çok eşliliğe karşı olma, harf inkılabı gibi Atatürk devrimlerini benimsemeye ilişkin konular gündeme gelmiştir. ${ }^{31}$ İkinci Kongre'nin sonucunda MP içinde ileride yaşanacak olan büyük bir anlaşmazlığın ilk kıpırtıları yaşanmış ve parti içinde "devrimci" ile "muhafazakâr-dinci" iki grubun var olduğu meydana çıkmıştır. ${ }^{32} \mathrm{Bu}$ iki grup arasındaki tartışmalar Üçüncü Kongre'de daha da alevlenmiştir. Hükümetten ve hükümete yakın kesimlerden MP'nin irticayı desteklediğine ilişkin kampanyaların başladığı bir süreç içinde MP’nin Dördüncü kongresi yapılmış ve kongrede Bölükbaşı, "tek parti zihniyetinin devam ettiği, hükümetin idareyi baskı altına aldığı" yönünde konuşma yapmıştır. Bununla birlikte Bölükbaşı, Bayar ile Menderes'in sözlerini tutmadıklarını ifade etmiş, 14 Mayıs'tan yalnızca şahısların değiştiğini belirtmiştir. ${ }^{33}$

MP ve temsil ettiği kesimin sesini duyurmak adına Bölükbaşı’nın yaptığı "gerçek”

\footnotetext{
${ }^{27}$ Baban, Politika Galerisi, Büstler ve Portreler, s.449-450.

${ }^{28}$ TBMM Tutanak Dergisi, C. 1, D: 9, Toplantı: Olğ, Beşinci Birleşim (2. 6.1950), s.142-143.

${ }^{29}$ Tarık Zafer Tunaya, İslamcılık Cereyanı, İstanbul: Bilgi Üniv. Yay., 2003, s.191-193, 203.

${ }^{30}$ Kudret, 03.03.1951.

${ }^{31}$ Vatan, 31. 05. 1951

${ }^{32}$ Çaylak, "Türk Siyasal Hayatında Osman Bölükbaşı", s.221.

${ }^{33}$ Çaylak, "Türk Siyasal Hayatında Osman Bölükbaşı”, s.222-249.
} 
muhalefet, partinin "laiklik karşıtı olmak" bahanesiyle kapatılmasına neden olmuştur. ${ }^{34}$ Menderes Hükümeti 1954 seçimlerinden önce iktidarını sağlamlaştırmak için muhalefet üzerinde sıkı bir baskı kurma politikası izlemiştir. ${ }^{35}$

MP kesin olarak kapatıldığı sıralarda, partililer MP hareketinde başarılı olunamayacağını anlamış ve 1954 seçimlerine yaklaşılırken kadronun yeniden toparlanması ve hareketin dağılmaması için yeni parti kurma çalışmalarını hararetlendirmişlerdir. Yapılan çalışmaların ardından 9 Şubat 1954'te CMP kurulmuştur. CMP'nin programı, MP’yi kapatılmaya kadar götüren süreç göz önünde bulundurularak oluşturulmuştur. CMP'nin programında, laiklik ve cumhuriyetçilik prensipleri açık bir şekilde belirtilmiştir. ${ }^{36}$

Kurulur kurulmaz 1954 seçimleri ile karşı karşıya kalan CMP açısından seçimler bir rejim davasıydı. Seçimler için CHP ile CMP işbirliği arayışı içerisine girse de CHP’nin güçlü olduğu bölgelerde CMP'li adayları listeye koymaktaki isteksizliği ve partiler arasındaki ideolojik uyuşmazlıklar yüzünden işbirliği gerçekleşmemiştir. 1954 seçim kampanyalarında Bölükbaşı iktidara yüklenmiş "ne tek parti zihniyetinden vazgeçtiler, ne tek parti zihniyetine mesnet olan kanunları kaldırdılar" biçiminde konuşmuştur. ${ }^{37}$

1954 seçimleri sonucunda DP'nin oyları \%58,4'e yükselmiş ve CHP’nin oyları \%35,1'e düşmüştür. Bu da çoğunluk sistemine göre mecliste DP'nin 503, CHP'nin ise 31 sandalyeye sahip olması demekti. CMP \%4,8'lik oy oranı ile 5 milletvekilliği almış ve hepsini de Bölükbaşı'nın memleketi Kırşehir'den sağlamıştı. DP’nin zirvede olduğu 1954 seçimleri aslında büyük bir düşüş olan sonunun başlangıç noktası olmuştu. Büyüyen ekonomik bunalım ve baskıcı politikalar egemen sınıfın bir kesiminin, aydınların ve ordunun hükümetten soğuması, DP'nin sonunu hazırlamıştı. ${ }^{38}$ DP’nin muhalefete karşı tahammülsüz politikaları, Kırşehir'i destekleyen halkı cezalandırmak için Kırşehir vilayetini yerel hizmetler açısından hiçbir fayda/zarar durumunu göz önüne almadan, tamamen siyasi bir kararla ilçe yapabilecek duruma getirmiştir. ${ }^{39}$

1957 seçimlerinin kaygısıyla DP, Kırşehir’i yeniden vilayet yapmak yönünde çalışmalara başlamıştır. Gergin bir ortamda geçen çalışmalarda Bölükbaşı söz istemiş, kendisine söz verilmeyince "utanın, zalimlerin uşakları, utanın, son söz milletvekilinindir" çıkışında bulunmuştur. Meclis başkanının "artık kimseye söz vermiyorum" demesi üzerine Bölükbaşı "topunuz ne olduğunuzu gösterdiniz. Haysiyetten mahrum insanlar" şeklinde konuşmuş ve "haysiyetiniz olsa bu kanunu çıkarmazdınız" şeklinde ağır sözler söylemiştir. Bu gelişmeler sonucunda Bölükbaşı, dokunulmazlığı kaldırılarak tevkif edilmiştir. 21 gün tutuklu kalan Bölükbaşı, 23 Temmuz'da tahliye edilmiştir. 25 Temmuzda yeniden tevkif edilmesine karar verilen Bölükbaşı, 1957 seçimlerini tutuklu olarak geçirmiştir. ${ }^{40}$

1957 seçimleri öncesinde de muhalefetin işbirliği arayışları sonuçsuz kalmıştır. 27 Ekim 1957 tarihinde yapılan genel seçimlerde DP \%47,7’lik oy oranıyla 424, CHP

\footnotetext{
${ }^{34}$ Adnan Ferruh Pancaroğlu, Yakın Tarihimizde Millet Partisi Olgusu (1948-1977), Yüksek Lisans Tezi, Afyonkarahisar Kocatepe Üniversitesi, 2006, s.48.

${ }^{35}$ Zürcher, Modernleşen Türkiye Tarihi, s.324-325.

${ }^{36}$ Çaylak, "Türk Siyasal Hayatında Osman Bölükbaşı", s.272-273.

${ }^{37}$ Çaylak, “Türk Siyasal Hayatında Osman Bölükbaşı”, s.274-281.

${ }^{38}$ Zürcher, Modernleşen Türkiye Tarihi, s.324-325.

${ }^{39}$ Çaylak, "Türk Siyasal Hayatında Osman Bölükbaşı", s.282-300.

${ }^{40}$ Çaylak, "Türk Siyasal Hayatında Osman Bölükbaşı”, s.351-379.
} 
\%40,8 ile 178, CMP \%7,19'luk bir oranla 4 sandalye kazanmıştır. DP açısından kulak asmadığı bir uyarı niteliğindeki bu seçimlerin akabinde seçimlerden bir ay sonra 30 Kasım 1957 tarihinde Bölükbaşı serbest bırakılmıştır. 1958 yılında iktidarla muhalefet arasındaki ilişkiler azami düzeyde gerilmiştir. DP, iyice otoriterleşmiş, toplantı ve gösterilerin yasaklandığı ve basın gibi hükümet dışı unsurlar üzerinde de baskı tesis edildiği bir siyasal ortamda muhalefetin serbestçe kendini ifade edebileceği biricik yer olan meclisin iç tüzükte değişiklik yapılarak sınırlandırılması, meclis gruplarının lağvedilmesi ve radyonun partizanca bir hale dönüşmesi türünden hadiseler DP iktidarının darbeye kadar gidecek olan sonunu belirlemiştir. CMP, bu dönemde DP iktidarı ve yetersiz CHP muhalefeti karşısında bir "üçüncü kuvvet”e olan ihtiyaç doğrultusunda TKP (Türkiye Köylü Partisi) ile birleşerek CKMP olarak yoluna devam etmiştir. ${ }^{41}$ Gerek bu birleşme ve gerekse Bölükbaşı'nın baskın lider karakteri, parti içinde huzursuzluklara neden olmuştur.

27 Mayıs Darbesi'ne giden süreçte muhalefet partilerinin aralarında Güç Birliği ismiyle birleşmesi DP tarafından endişe ile karşılanmış ve muhalefetin karşısında "Vatan Cephesi" kurma gayreti içine düşmüştür. Buna göre radyoda partiye üye olanların adları okunmuştur. CKMP de, "Milletçe Demokrasiyi Kurma Davamızda Çıkar Yol Beyannamesi” adlı tebliği yayımlamış, tebliğde halihazırdaki anayasanın yetersizliği, milli bir anayasanın milletçe yapılması gerektiği ve seçimlerin nispi temsil sistemiyle yapılmasının daha adil olacağ düşüncelerine yer verilmiştir. ${ }^{42}$

Muhalefete karşı sert tedbirlerini devam ettiren DP, 18 Nisan 1960'ta muhalefetin faaliyetlerini soruşturmak üzere geniş yetkileri olan Tahkikat Komisyonu'nu kurmuştur. Bu komisyon hukukçular tarafından anayasaya aykırı olmakla suçlanmış ve hukuk profesörlerine verilen disiplin cezaları öğrenci ayaklanmalarıyla karşılanmıştır. ${ }^{43}$

Bütün bu hadiselere dek suskun kalan ordu, en sonunda hükümet değişikliği, demokrasiye uygun olmayan kanunların kaldırılması, siyasi suçluların affedilmesine iliş̧in taleplerde bulunmuştur. ${ }^{44} 23$ Mayıs 1960'ta Bölükbaşı hükümet hakkında 28 Nisan'da gerçekleşen öğrenci ayaklanmalarında yaşanan ve ölümle sonuçlanan ihlallerle ilgili meclis soruşturması isteyen bir önerge vermiştir. 25 Mayıs 1960'ta Bölükbaşı, iktidarı darbeye yol açmakla itham etmiş, dürüstçe bir seçim için karar alınmadığı takdirde memleketin kardeş kavgasına gideceği uyarısında bulunmuştur. ${ }^{45} \mathrm{Bu}$ uyarılar yapıldı̆̆ında artık iş işten geçmiş olsa da önceden yapilan hiçbir eleştiri ve uyarıya kulak asmayan DP iktidarı, 27 Mayıs 1960 tarihinde MBK (Milli Birlik Komitesi) tarafından ülkenin yönetimine el koymasıyla son bulmuştur.

\section{Mayıs ile 12 Mart Arasında Osman Bölükbaşı}

27 Mayıs darbesi sonrasında MBK’nin kabul ettiği geçici anayasa süresi boyunca, tüm siyasi faaliyetler yasaklanmıştır. CHP ve CKMP varlığını korumuşsa da il ve ilçe teşkilatları haricinde teşkilatlanmaları yasaklanmıştır. MBK içinde, darbeden sonra "yönetimi derhal sivil bir idareye bırakmanın gerekli olduğunu düşünenler"

\footnotetext{
${ }^{41}$ Çaylak, “Türk Siyasal Hayatında Osman Bölükbaşı”, s.397-408.

${ }^{42}$ Cumhuriyet, 21.01.1959.

${ }^{43}$ Zürcher, Modernleşen Türkiye Tarihi, s.349-350.

${ }^{44}$ Eroğul, Demokrat Parti, s.247.

${ }^{45}$ Kudret, 13.10.1960.
} 
ile "demokratik nizam tesis edilinceye dek yönetimin orduda kalması gerektiğini düşünenler" arasında bir gerilim yaşanmıştır. ${ }^{46}$

Bölükbaşı 27 Mayıs darbesini alkışlamamışsa da, darbe sonrası yapılan anayasada kendisinin yıllardır savunduğu ilkelerin yer alması ve hepten otoriterleşen DP'nin tüm uyarılara kulak asmaması karşısında Bölükbaşı'nın darbeye tepkisi olumsuz olmamıştır. Zira MP, CMP, CKMP programlarında en baştan beri var olan çift meclisli sistem, anayasa mahkemesinin kurulması, güçler ayrılığı, nispi temsil sistemi vb. yeniliklere darbenin sonucunda kabul edilen 1961 Anayasası'nda yer verilmiştir. Bununla birlikte DP döneminde partisi kapatılmış, sadece kendisini seçmiş olması gerekçesiyle memleketi ilçeye dönüştürülmüş, birkaç kez hapse mahkûm edilmiş, sürekli olarak iktidar tarafından baskı altında kalmış olan Bölükbaşı, "1946 ruhu" söylemiyle DP’nin kuruluşuna katkı sağlamış liderlerden biri olduğu için, kendi hareketinin DP oylarını tevarüs edebileceğini düşünmüştür. Ancak olaylar, Bölükbaşı'nın beklediği gibi olmamış, Cemal Gürsel'in onayıyla Ragıp Gümüşpala liderliğinde AP (Adalet Partisi) ve Ekrem Alican liderliğinde YTP (Yeni Türkiye Partisi), DP’nin mirasçıları olarak kurulmuşlardır. Bu olaylar sonucunda "meşruiyetini yitirmiş bir iktidara karşı" darbe yapan MBK ile arasını iyi tutan Bölükbaşı'nın, askerle de arası açılmış ve böylece Bölükbaşı 1960’lı yıllarda da muhalefet bayrağını taşımıştır. ${ }^{47}$

Aslında CKMP ile MBK arasındaki ilk anlaşmazlık Kurucu Meclis'in oluşum tarzı konusunda ortaya çıkmıştır. Kurucu Meclis'in seçim yapılmadan oluşturulması yönündeki söylentiler Bölükbaşı'yı rahatsı etmiş ve böylesi bir durumun siyasi krizi kaldırıp güvenilir bir düzen kurmaya hizmet etmeyeceğini ve Kurucu Meclis'de bir partiye ağırlık vermenin yanlış olduğunu ifade etmiştir. Bölükbaşı, isim vermeden CHP'yi kastetmek istediği ortadadır. ${ }^{48}$

Bölükbaşı, AP ve YTP’nin, DP oylarını paylaşıp CKMP’ni iktidara getirmemek kastıyla kuruldukları düşüncesindeydi. ${ }^{49}$ AP kurulduktan kısa süre sonra propagandalarını askeri rejime ve yeni anayasaya karşı yürütmüştür. Yeni dönemde DP'nin en güçlü mirasçısı olarak işaret edilen AP, MBK'nin tepkisini çekmiş ve MBK 31 Ağustos 1961 tarihinde siyasi parti temsilcileriyle bir toplantı düzenlemiştir. MBK ve siyasi parti temsilcilerinin hazırladığı ortak bildiri 5 Eylül'de yayımlanmış ve 27 Mayıs'in ve Yassıada'da alınacak olan kararların meşruiyetinin tartışmaya kapalı olması kararlaştırılmıştır. Aynı gün Cumhurbaşkanı Cemal Gürsel, siyasi parti liderleriyle yuvarlak masa toplantısı düzenlemiş ve bu toplantıya Bölükbaşı katılmamış, yerine Ahmet Oğuz’u göndermiştir. Sonrasında yapılan hiçbir yuvarlak masa toplantısına Bölükbaşı dâhil olmamış ve böylece askeri yönetimin dayattığı metinleri imzalama sorumluluğundan kendini kurtarmıştır. Gürsel'in tarafsızlığına güvenmeyen Bölükbaşı ile Gürsel arasındaki gerginlik bu gelişmelerin sonucunda ortaya çıkmıştır. Bölükbaşı Yassıada'dan Menderes, Zorlu ve Polatkan için çıkan idam cezalarının başka cezalara çevrilmesi gerektiğini savunmuştur. Buna karşın Gümüşpala'nın, yuvarlak masa toplantılarında bir taraftan Yassıada'dan idam kararı çıkacak olsa bile kararın meşruiyetini tartışmamaya söz verip

4627 Mayıs'tan MBK içindeki tasfiye sürecine kadar olan sürecin iyi bir özeti için bkz. Cengiz Sunay, "27 Mayıs'tan 13 Kasım'a Milli Birlik Komitesi”, (MECAS II, Sempozyumunda Sunulan Bildiri, International Vision University, Ohri, Ekim 10-13, 2017, cilt 1, s.155-167.

${ }^{47}$ Çaylak, "Türk Siyasal Hayatında Osman Bölükbaşı”, s.446.

${ }^{48}$ Kudret, 25.11.1960.

${ }^{49}$ Cumhuriyet, 10.10.1961. 
diğer taraftan da DP'nin seçmen kitlesine kendisini partinin mirasçısı olarak göstermek adına "şefkat toplantıları" düzenleyip Menderes ve arkadaşlarının kurtarılması için çalıştıkları imajını verdiğini iddia etmiştir..$^{50}$

1961 seçimlerine giderken Bölükbaşı’nın seçim propagandalarında kullandığı üslup MBK'ni taraflı olmakla suçlar nitelikteydi. Ayrıca Bölükbaşı, AP'yi MBK ile bir tutarak halkın gözünde itibarsızlaştırma çabalarına girmiştir. ${ }^{51}$ Seçim yaklaştıkça Bölükbaşı, ilk başlarda övgüyle söz ettiği 27 Mayıs'a karşı üslubunu sertleştirmiştir. Tahakküm alışkanlığından kurtulamayanların "devlet biziz” şeklindeki tutumlarıyla baskıya başvurduklarını ifade Bölükbaşı, 1961 Anayasası hakkında müspet tutumunu sürdürmeye devam etmiş ama haklara ve özgürlüklere önem veren 61 Anayasası'nın sadece haklara ve özgürlüklere samimiyetle bağlı olanlarca uygulanabileceğini belirtmiştir. Kimseden korkmadığını, hiçbir gücün himayesinde bulunmadı̆̆ını vurgulayan üslubuyla Bölükbaşı, 15 Ekim 1961 seçimlerine gelene kadar sık sık MBK ile karşı karşıya kalmış ve Gümüşpala'nın MBK ve CHP ile muvazaa içinde olduğuna ilişkin algı oluşturma çalışmalarına girişmiştir. Parti programında köylü sorunlarına, ilim ve teknikle beraber milli ve ahlaki değerlere dayanan eğitime ve özel girişime dayanan ama aynı zamanda planlı ve devlet destekli olan milli bir ekonomiye yer veren Bölükbaşı, MBK'ne darbenin kansız sonuçlanmasını ve Yassıada'daki idam cezalarının onaylanmamasını talep eden bir mektup göndermiştir. ${ }^{52}$

Böylesi bir atmosferde nispi temsil sistemine göre gerçekleştirilen 1961 CKMP $\% 13,96$ 'lk bir oy yüzdesiyle mecliste 54 sandalye kazanmıştır. AP $\% 34,80$ oy yüzdesiyle 156 vekil, CHP \%36,80 ile 173 vekil, YTP ise $\% 13,70$ oy yüzdesiyle 64 vekil kazanmıştır. ${ }^{33}$ "Kapatılan Demokrat Parti'nin ardılı siyasetçi ve seçmen açısından zafer" olarak nitelendirilen seçimlerden DP'nin mirasçlları olarak görülen AP ve YTP'nin yüksek oylarla çıkmaları orduda tedirginliğe neden olmuştur. ${ }^{54} \mathrm{CKMP}$ ise 1,5 milyona yakın seçmen kitlesiyle güçlü ve hükümetin kurulmasında kilit rol oynayan bir muhalefet parti durumuna gelmiştir.

CHP'nin tek başına iktidar olamamasının ordu içinde yarattığı tedirginlik, $27 \mathrm{Ma}$ yıs'tan sonra yönetimi sivil idareye devretmek istemeyenlerin harekete geçmesine neden olmuştur. SBK (Silahlı Kuvvetler Birliği) adında orduda etkili olan bir grup subay meclis yeniden açılmadan önce bir müdahalede bulunma kararı almış ve 21 Ekim 1961 günü toplanarak bir protokol imzalamıştır. Protokole göre, meclis toplanmadan duruma el konulacak, siyasi partilerin faaliyetleri yasaklanacak, seçim sonuçları geçersiz sayılacak ve MBK feshedilecekti. ${ }^{55}$ Ordunun vesayeti altında toplanan mecliste Cemal Gürsel, Cumhurbaşkanı seçilmiştir. Hükümetin kurulmasında kilit role sahip olan Bölükbaşı, koalisyona katılmayacağını, ancak hükümet kurulmasını da güçleştirmeyeceğini belirtmiştir. Güven oylamasında çekimser oy kullanan Bölükbaşı, CHP-AP koalisyon hükümeti kurulduktan kısa bir süre sonra partisinden istifa etmiştir. Bölükbaşı istifa nedenini açıklamamıştır. Ancak söz ko-

\footnotetext{
${ }^{50}$ Çaylak, “Türk Siyasal Hayatında Osman Bölükbaşı”, s.474-480.

${ }^{51}$ Cumhuriyet, 05.10.1961.

${ }^{52}$ Çaylak, “Türk Siyasal Hayatında Osman Bölükbaşı”, s.483-486.

${ }^{53}$ Nermin Abadan, 1965 Seçimlerinin Tahlili, Ankara: Sevinç Matbaası, 1966, s.335.

${ }^{54}$ Feroz Ahmad ve Bedia Turgay Ahmad, Türkiye’de Çok Partili Politikanın Açıklamalı Kronolojisi: 1945-1671, İstanbul: Bilgi Yayınları, 1976, s.329.

${ }^{55}$ Şükrü Karatepe, Darbeler, Anayasalar ve Modernleşme, İstanbul: İz Yay., 3. Baskı, 1999, s.222-223.
} 
nusu dönemde CKMP içinde çıkan anlaşmazlıklar olduğu bilinmektedir. Bölükbaşı, iddialara göre geri dönmek için partideki muhaliflerin ihraç edilmesini şart koşmuş ancak nihayetinde ssrarlar üzerine istifasını geri almıştır. Bu dönemde CKMP'nin muhalefeti 27 Mayıs Darbesi'nin siyasi mahkûmlarının affı konusunda hükümete baskı yapmak üzerine şekillenmiştir. ${ }^{56}$

CKMP içinde, 1950'li yıllardan itibaren mevcut hizipleşmeler 27 Mayıs sonrasında yapılan seçimlerde alınan düşük oylar nedeniyle yeniden su yüzüne çıkmıştır. Partinin seçimlerdeki başarısızlı̆̆ında ekip ruhu tanımayan, şahsi ve keyfi bir tutum sergilediği iddia edilen Bölükbaşı sorumlu tutulmuş ve onun güçlü liderliği eleştirilmiştir. Parti içinde yaşanan bu huzursuzluk ve hizipleşmeler sonucunda Bölükbaşı, 1962 yılının mart ayında parti başkanlığından kesin olarak istifa etmiştir. I. İnönü Hükümeti'nin siyasi suçluların affı meselesindeki anlaşmazlıktan dolayı, İnönü’ nün istifasıyla yıkıldığı sırada Bölükbaşı partisinden tamamen istifa etmiş ve sadece Ankara milletvekilliği görevini yürütmeye başlamıştır. Bölükbaşı, DP tarafından 1954 yılında kapatılan MP'yi 16 Haziran 1962 yılında yeniden kurmuştur. Yeni kurulan MP'nin, eskisinden büyük bir farkı yoksa da din konusunda daha ihtiyatlı bir dil kullanılmıştır. MP'nin siyasal sistemde yerini almasıyla birlikte CKMP ile MP arasında çatışmalar başlamıştır. İnönü istifa etmeden önce yeni bir koalisyon için çalışmalara başlamıştır. CKMP, koalisyona girerek Bölükbaşı karşısında güç kazanma hesapları içine girmiştir. İnönü, koalisyon kurmadan önce Bölükbaşı ile görüşmek istemiş, Bölükbaşı CKMP'nin olduğu hükümeti MP'nin desteklemeyeceğini söylemiştir. Hükümet kurması iyice zorlaşan İnönü istifa etmek istemiş ancak Gürsel, istifayı kabul etmemiştir. İnönü de milletvekillerinin desteğini sağlayarak CHP-YTP-CKMP ve bağımsızlardan oluşan koalisyon hükümetini kurmuştur. Ancak bu hükümet uzun süre varlığını devam ettirememiş ve 2 Aralık 1963 'te İnönü bir kez daha istifa etmiştir. ${ }^{57}$

Cemal Gürsel, hükümet kurma görevini Ragıp Gümüşpala'ya verse de, Gümüşpala hükümet kuramamış ve nihayetinde İnönü 25 Aralık 1963'te bağımsızlardan müteşekkil üçüncü koalisyonu kurmuştur. Ancak Eylül 1964'ten itibaren Kıbrıs sorunu nedeniyle bu hükümet zor zamanlar yaşamıştır. Kıbrıs meselesinin vahamet kesp etmesi üzerine Bölükbaşı, bütün partileri bir tür "milli cephe" kurmaya çağırmış, fakat AP bu çağrıya yanaşmamıştır. Gümüşpala'nın vefatı üzerine 1964 yılının Kasım ayına AP başına Süleyman Demirel geçmiştir. Demirel'in geldiğinden itibaren ilk icraatı İnönü hükümetini yıkmaya yönelik olmuştur. Bölükbaşı "CHP'siz hükümet kurulamaz ve kurdurulamaz şeklinde, ihtilalden beri devam ettirilen propagandalarla...vvatandaş kitlesinde rejimin yarını hakkında bir endişe hâkim olmuştur" şeklindeki sözlerinden anlaşıldığı üzere CHP’siz hükümet kurulması konusunda son derece isteklidir. Bu çerçevede Bölükbaşı, CHP’nin başında olduğu koalisyon hükümetini yıkmak üzere çalışmalar yapan Demirel'i desteklemiştir. Sonucunda III. İnönü hükümeti 13 Şubat 1965'te bütçe aleyhine verilen 225 oyla düşürülmüştür. ${ }^{58}$

1965 seçimlerine gelene kadar geçen süreçte AP’li Suat Hayri Ürgüplü hükümeti kurmakla görevlendirilmiştir. 20 Şubat 1965'ten 27 Ekim 1965 tarihine kadar görev yapan bu hükümet dönemi, Bölükbaşı'nın ve partisi MP'nin iktidarı ilk ve son kez

${ }^{56}$ Çaylak, “Türk Siyasal Hayatında Osman Bölükbaşı”, s.488-499.

${ }^{57}$ Çaylak, "Türk Siyasal Hayatında Osman Bölükbaşı”, s.499-527.

${ }^{58}$ Çaylak, "Türk Siyasal Hayatında Osman Bölükbaşı", s.527-542. 
tattı̆̆g dönemdir. Bu dönemde Bölükbaşı, 1 Mayıs 1964'te kurulan TRT'yi CHP’nin sözcüsü olarak görmüş ve TRT’yi sert bir üslupla eleştirmiştir. Bununla birlikte, komünizmin Türkiye için en büyük tehlike olduğunu belirten Bölükbaşı, Rusya ile imzalanan kültür antlaşmasının büyük bir siyasi basiretsizlik örneği olarak görmüştür. Bölükbaşı'ya göre, sosyalizmle mücadele hayati bir öneme sahiptir ve bunun için en etkin yöntem, sosyal adaleti tesis etmektir. ${ }^{59}$

1965 yılında seçim sisteminin küçük partileri temsil sisteminde daha avantajlı kılan "milli bakiye sistemi” şeklinde değiştirilmiştir. 10 Ekim 1965 tarihinde yapılan seçimlerde MP, Bölükbaşı'yı destekleyen sabit seçmen kitlesini kaybetmemiş, \%6,26 oy oranıyla meclise 31 milletvekili göndermiştir. \%52,87 oyla, milli bakiye sistemine rağmen tek başına hükümet kurmayı başarabilen AP, DP'nin mirasçısı olduğunu ispatlamış ve Bölükbaşı'nın iktidar beklentisi gerçekleşmemiştir. DP döneminde yaptığı gibi, yeniden muhalefet bayrağını eline alan Bölükbaşı, geçiş döneminin bitmediğini ve hükümetin suni bir iyimserliğe kapıldığını söylemiştir. Bölükbaşı, AP hükümetini ölçüsüz vaatler vermekle suçlamıştır. Ayrıca, AP’nin milli bakiye seçim sisteminde yapmak istediği değişiklikle muhalefeti tasfiye etmek istediğini ve tıpkı selefi DP gibi tek başına meclise hâkim olmak istediğini iddia etmiştir. Bölükbaşı ayrıca, Demirel'i din istismarı yapmakla suçlamış ve Batı ile işbirliği içinde olduğunu vurgulamıştır. ${ }^{60}$

28 Mart 1966'da Cumhurbaşkanı seçilen Cevdet Sunay'ı, Bölükbaşı desteklememiştir. Bölükbaşı bunun nedenini "gerçek demokrasi ile yönetilen ve milli iradenin saygı gördüğ̈̈ hiçbir memlekette, Ordu'nun başında bulunan bir zatın Cumhurbaşkanı olduğu görülmemiştir" sözleriyle ifade etmiştir. ${ }^{61}$ Bölükbaşı, her ne kadar AP'nin ve Demirel'in Batı emperyalizminin maşası olduğunu vurgulayan ve askeri vesayeti olumsuzlayıp millet iradesi ve demokrasiyi öven konuşmalar yapsa da kısmi senato seçimleri MP için hüsranla sonuçlanmış, AP oyların yarısından fazlasını $(\% 56,29)$ alarak 35 senatörlük kazanırken, MP, çekirdek oylarının da altına düşerek $\% 5,9$ oy yüzdesiyle sadece 1 senatörlük kazanmıştır. ${ }^{62}$

1965 genel seçimleri ve 1966 kısmi senato seçimlerinde hayal kırıklığı yaşayan Bölükbaşı, 1966 yılının sonlarında sağlık gerekçesiyle MP genel başkanlığından istifa etmiştir. Altı ay kadar istirahata çekilen Bölükbaşı, yeniden genel başkan seçileceği Mart 1967’ye dek sadece önemli meclis oturumlarına katılmıştır. Partinin seçimlerdeki başarısızlığı parti içinde anlaşmazlıklara neden olmuştur. Bölükbaşı'yı en çok üzen mesele ise, parti içindeki yol arkadaşlarının istifa edip başka partilere kaçmalarıdır. Ancak Bölükbaşı her şeye rağmen pes etmemiş ve 1969 seçimlerine partisini güçlü bir şekilde sokmak adına 1967’den itibaren bir hayli ilgi gördüğü yurt gezilerine başlamıştır. Gezilerde yaptığı konuşmalarda, rakiplerine sert bir şekilde yüklenmiştir. Bölükbaşı'nın rakiplerini tenkitleri, AP ve CHP gibi partilerin Batılı güçlerin ve komünizmin işbirlikçiliğini yaptığı yönünde olmuştur. 1969 seçimlerine yaklaşıldığg günlerde, MP, 1965 seçimlerinde parlamentoya soktuğu milletvekillerinin çoğunu kaybetmiştir. Bölükbaşı'nın sayesinde meclise giren vekiller bir bir partilerini ve Bölükbaşı' yı terk etmişlerdir. ${ }^{63}$

\footnotetext{
${ }^{59}$ Çaylak, “Türk Siyasal Hayatında Osman Bölükbaşı”, s.547-560.

${ }^{60}$ Çaylak, "Türk Siyasal Hayatında Osman Bölükbaşı”, s.564-575.

${ }^{61}$ Çaylak, "Türk Siyasal Hayatında Osman Bölükbaşı”, s.575.

${ }^{62}$ Ahmad ve Ahmad, Türkiye'de Çok Partili Politikanın Açıklamalı Kronoojisi:1945:1971, s.313.

${ }^{63}$ Çaylak, “Türk Siyasal Hayatında Osman Bölükbaşı”, s.585-598.
} 
12 Ekim 1969 seçimlerinde Bölükbaşı yine istediği başarıyı elde edememiş, sert bir düşüşle \%3,22'lik bir oy oranıyla mecliste 6 sandalye kazanabilmiştir. Seçim, yine AP’nin zaferi ile sonuçlanmıştır. ${ }^{64}$ Bu dönemlerde Konya'dan bağımsız olarak meclise giren Necmettin Erbakan tanınmaya başlamış ve Bölükbaşı, Erbakan'ı partisine çekmek isterken, Erbakan, MP'nin genel başkanlığını istemiş ve Bölükbaşı bu isteğe olumlu bakmamıştır. Yaşanan bu gelişmeler, MP içerisinde "Bölükbaşı taraftarları" ile "Bölükbaşı karşıtları" şeklinde bir kutuplaşmayla sonuçlanmıştır. Ancak Mayıs 1970’te partinin Dördüncü Büyük kongresinde büyük tartışmaların ardından Bölükbaşı yine genel başkan seçilmiştir. ${ }^{65}$

Diğer taraftan, ülkede sağ-sol çatışmaları ve Ordu'yu siyasete sokacak olayların artışıyla, 1971'in başlarından beri, Cumhurbaşkanı Sunay'ın önderliğinde, partilerin liderleri toplanmaya başlamışlardır. Gergin bir duruma gelen öğrenci hareketleri meselesinde, Sunay'in parti liderleriyle ve üniversite temsilcileriyle yaptığı görüşmelerle alakalı Bölükbaşı açıklama yapmıştır. Sunay'ın parti liderleriyle olan görüşmelerine davet edilmeyen Bölükbaşı, açılamasında Cumhurbaşkanı seçilmesinden itibaren Sunay'ın iktidar partisiyle birlik halinde olduğu ve ülkeyi çıkmaz bir yola sokan hükümetin ve medyanın pervasızlığının dayanağının Sunay olduğunu ifade etmiştir. Bölükbaşı, AP iktidarı döneminde, Türkiye'nin zorbaların kol gezdiği, kışkırtılmış ve teşkilatlandırılmış kitlelerin sokaklarda vuruşturulduğu, hükümet merkezi Ankara'da bile can emniyetinin kalmadığ 1 bir ülke durumuna düşürüldügünü söylemiştir. Demokrasiyi uçuruma götüren menfaatçi siyasetin karşısında, bir "milli cihat” zorunluluğunu belirten Bölükbaşı, bütün bu hadiselerin müsebbibi olan Sunay'ı istifaya çağırmıştır. ${ }^{66}$

Sonuçta Ordu 12 Mart 1971 tarihinde Cumhurbaşkanı ve Meclis Başkanlarına muhtıra vermiş ve AP Hükümeti istifa etmiştir. Sonrasında, Cumhurbaşkanı Sunay, demokratik bir çözüm bulunabilmesi hususunda parti temsilcilerinden görüş talep etmiştir. Bu hususta Bölükbaşı, tarafsız birinin başkanlığında ve meclisin iki kanadında büyük çoğunluğa sahip olan partilerin katılacağı bir koalisyon hükümeti temenni ettiğini belirten bir yazı göndermiştir. ${ }^{67}$

Bölükbaşı'nın katıldığı son kongre ve partisi MP adına yaptığı son konuşma 20 Kasım 1972 tarihindeki Beşinci Kongre'de olmuştur. Yaptığı konuşmada, muhtıranın nedenlerine değinen Bölükbaşı, "12 Mart'ta subayın yaptı̆̆ harekette bir saltanat yoktur... Amma biz intibaha gelmezsek, geçmişte ne olmuşsa gelecekte de, o olacaktır" demiştir. Yaşanan olaylar sonucunda siyasetten soğuyan Bölükbaşı, 14 Ekim 1973 tarihindeki seçimi bile beklememiş, 9 Eylül 1973'te partisinden ve milletvekilliğinden istifa etmiştir. ${ }^{68}$

Siyasete atıldığı ilk yıllardan itibaren, tek kişi, tek zümre yönetimine karşı çıan ve iktidarın anayasal denetime tabi olduğu, hukuk devleti ilkesine dayalı çoğulcu milli irade yönetimi savunan söylemleriyle, DP ve AP iktidarlarına ve onların muvazaacıları olarak gördüğü muhalefetlere karşı en sert ve en gerçek muhalefeti etmiş Bölükbaşı'nın serazat siyasi hayatı böylece sona ermiştir.

\footnotetext{
${ }^{64}$ Ahmad ve Ahmad, Türkiye'de Çok Partili Politikanın Açılamalı Kronolojisi, s.376.

${ }^{65}$ Çaylak, "Türk Siyasal Hayatında Osman Bölükbaşı", s.598-603.

${ }^{66}$ Cumhuriyet, 06.01.1971.

${ }^{67}$ Zafer; Cumhuriyet, 17.03.1971.

${ }^{68}$ Çaylak, "Türk Siyasal Hayatında Osman Bölükbaşı”, s.606-611.
} 


\section{Sonuç}

CHP'nin tek parti iktidarından çok partili demokratik bir sisteme geçme noktasında CHP'den kopan milletvekilleri DP'yi kurmuşlardır. Ancak DP bünyesinde yer alan ve onu destekleyen herkes, tek parti iktidarı döneminde CHP'den memnun kimseler değildir. İşte Bölükbaşı, bu memnuniyetsizler arasındadır. Siyasi hayatının başlangıcından itibaren demokrasi, hürriyet, çoğulculuk, iktidarın denetlenmesi gibi hassasiyetler taşıyan Bölükbaşı, siyasi hayatına bünyesinde başladığı ve kuruluşunda aktif rol oynadığı DP’yi, yine aynı hassasiyetler nedeniyle terk etmiştir. Bölükbaşı DP’yi, muhalefette olduğu yıllarda CHP ile muvazaa hâlinde olmakla; iktidara geldiği yıllarda da CHP'nin, tek parti zihniyetini farklı söylemlerle devam ettiren bir kopyası olmakla suçlamıştır. Bu açıdan Bölükbaşı ve liderliğini yaptığı hareketi, sadece iktidara karşı bir muhalefetten ziyade, muhalefete karşı bir muhalefet olarak da değerlendirmek gerekir.

Siyasete başladığı ilk yıllardan beri, nispi temsil sistemi, anayasa mahkemesi, çift meclis gibi temsilde adaleti sağlayan ve iktidarı denetleme mekanizmalarına önem veren kurum ve ilkelerini savunan Bölükbaşı, 27 Mayıs darbesini ilkesel olarak olumsuz karşılamamıştır. Zira onun başından beri savunduğu ve dile getirdiği kurum ve ilkeler, darbeden sonra kabul edilen 1961 Anayasası'nda aynen kabul edilmiştir. Bu noktada Bölükbaşı'nın, "demokrasi gelsin de nasıl gelirse gelsin" gibi bir anlayışa sahip olduğu değerlendirilebilir. Ayrıca ona göre darbe, zaten meşruiyetini yitirmiş bir iktidara karşı yapılmıştır. Bu yüzden ilk zamanlarda 27 Mayıs'ın meşruiyetini sorunlu görmeyen Bölükbaşı, sonrasında kendisinin güçlenmemesi için Ordu desteğiyle iki muhalefet partisi açılınca, Kurucu Meclis'te en büyük ağırlık CHP'ye verilince ve yuvarlak masa toplantılarında 27 Mayıs'ın meşruiyeti Yassıada'da çıkacak idam kararlarına rağmen tartışmaya kapatılınca, darbenin bir zümrenin iktidarının yerine başka bir zümrenin iktidarını geçirmekten başka bir amaca hizmet etmediğini çok geçmeden anlamıştır.

27 Mayıs'ın umduğu demokratik hukuk devleti mekanizmalarını sadece göstermelik olarak getirdiği sonucuna varan Bölükbaşı, 12 Mart muhtırasına kadar geçen süreçte (1965'te kurulan 29. Hükümet hariç) muhalefet olarak kalmaya devam etmiştir. Bu dönemde Bölükbaşı'nın muhalefetinin hedefinde Ordu'nun taraflı tutumu, AP'nin Amerikan emperyalizminin maşası olması ve iktidar ve muhalefetin komünizmle etkili bir biçimde mücadele edememesi vardır. Bu doğrultuda dış ilişkiler ve ekonomi alanında yürütülen politikalara muhalefet eden Bölükbaşı, 12 Mart'ı da, tek parti zihniyetinin asla son bulmamış olmasının doğal bir sonucu olarak görmüştür.

CHP, DP, AP ve Ordu’ya karşı en güçlü oldukları dönemlerde bile korkusuzca ve sert bir üslupla muhalefet eden Bölükbaşı, dinin devletin egemenliği altında olmasını sorunlu olarak görmüş ve parti liderlerinin oy kaygısıyla dini kullanmalarına karşı çıkmıştır. Bu yüzden "laiklik karşıtı" ve "gerici” olmakla suçlanmışsa da Bölükbaşı hiçbir zaman şartlara göre pragmatik davranmakla suçlanamamıştır. $O$, asla ikbal kaygısıyla başından beri savunduğu demokrasi, hürriyet ve çoğulculuğa ilişkin değerlerden taviz vermemiştir. Sert ama esprili üslubuyla meydanlarda halk tarafından büyük bir teveccüh gören ve coşkuyla karşılanan Bölükbaşı, inandığ 1 değerler uğruna, uzlaşmaz ve taviz vermez tutumuyla, elde ettiği iktidar fırsatlarını değerlendirmemiştir. Böylece 27 yıllık siyasi hayatında hep muhalefet bayrağını 
elinde tutan Bölükbaşı, siyasal akılda: "MP, tek başına iktidar olma şansı yakalasayd, halâ nispi temsil sistemi, anayasa mahkemesi, çift meclis gibi demokratik mekanizmaları savunacak mıydı?” sorusunu bırakmıştır.

\section{Kaynakça}

Abadan, Nermin. 1965 Seçimlerinin Tahlili. Ankara: Sevinç Matbaası, 1966.

Ağaoğlu, Samet. Aşina Yüzler. İstanbul: Ağaoğlu Yayınları, 1956.

Ahmad, Feroz ve Bedia Turgay Ahmad. Türkiye'de Çok Partili Politikanın Açıklamalı Kronolojisi: 1945-1971. İstanbul: Bilgi Yayınları, 1976.

Baban, Cihad. Politika Gazetesi: Büstler ve Portreler. İstanbul: Remzi Kitabevi, 1940.

Başkent Gazetesi, 18.11.1946.

Bayar, Celal. Başvekilim Adnan Menderes. İstanbul: Baha Matbaası, 1969.

Bayur, Hikmet. "Millet Partisi". Kudret. 20.07.1948.

Cumhuriyet Gazetesi, 06.01.1971.

Cumhuriyet Gazetesi, 17.03.1971.

Çaylak, Adem. “Türk Siyasal Hayatında Osman Bölükbaşı. Doktora Tezi, Ankara Üniversitesi, 2004.

Eroğul, Cem. Demokrat Parti. İstanbul: İmge Yayınları, 1990.

Heper, Metin. "Special Issue on Civil Military Relations in Turkey Introduction". Journal of Turkish Studies. 12/2 (2011) (erişim 3.06.2021).

Karatepe, Şükrü. Darbeler, Anayasalar ve Modernleşme. İstanbul: İz Yay., 3.b. 1999.

Karpat, Kemal. Türk Demokrasi Tarihi. İstanbul: Timaş Yayınları, 2010.

Keyder, Çağlar. Türkiye'de Devlet ve Sınıflar. İstanbul: İletişim, 3. Baskı, 1993.

Kudret Gazetesi, 03.03.1951.

Kudret Gazetesi, 29.04.1950.

Kumbaracıbaşı, Arda Can. "Cumhuriyet Halk Partisi Oylarının Birikimli Düzey Analizi ve Türkiye’de Merkez Solun Seçim Coğrafyasının İncelenmesi”. Amme İdaresi Dergisi. 47/4 (2014): 59-92.

Mardin, Şerif. Türkiye'de Toplum ve Siyaset. İstanbul: İletişim, 1991.

Nesimi, Abidin. Yılların İçinden. İstanbul: Gözlem Yayınları, 1977.

Pancaroğlu, Adnan Ferruh. "Yakın Tarihimizde Millet Partisi Olgusu (19481977)”. Yüksek Lisans Tezi, Afyonkarahisar Kocatepe Üniversitesi, 2006.

Sadak, Necmettin. "Demokrat Partiye Hoş Geldin Deriz”. Akşam. 09.01.1946.

Sunay, Cengiz ve Ataseven. Emrullah. "Prelude To A Coup, The Press and The May 27 1960". Current Research in Social Science. $3 / 3$ (2017): 143-153.

Sunay, Cengiz. “27 Mayıs'tan 13 Kasım'a Milli Birlik Komitesi” MECAS II, Kongresinde Sunulan Bildiri, International Vision University, Ohri, Ekim 1013, 2017.

TBMM Tutanak Dergisi. C. 1, Dönem: 9, Toplantı: Olğ, 5’inci Birleşim (2. 6.1950).

Toker, Metin. Tek Partiden Çok Partiye. İstanbul: Milliyet Yayınları, 1970.

Tunaya, Tarık Zafer. İslamcılık Cereyanı. İstanbul: Bilgi Üniversitesi Yay., 2003.

Vatan Gazetesi, 31.05.1951.

Zafer Gazetesi, 17.03.1971.

Zürcher, Eric Jan. Modernleşen Türkiye Tarihi. İstanbul: İletişim, 2000. 